РОЛЬ РИЗИКУ В ДЕТЕРМІНАЦІЇ ПОВЕДІНКИ СПОЖИВАЧА

\title{
THE ROLE OF RISK IN DETERMINING CONSUMER BEHAVIOR
}

УДК 303.4:316.334.2

DOI https://doi.org/10.32843/2663-

5208.2020.19.3

\section{щерба О.І.}

к.соціол.н., доцент,

науковий співробітник відділу

соціальної антропології

Інститут народознавства

Національної академії наук України
У статті розглянуто теоретичні основи вивчення ризику як одного з визначальних детермінант споживчої поведінки індивідів таких дослідників, як У. Бек, Р.А. Бауер, В.В. Мітчел, Л. Гарбарський, Л. Рудницький, А. Джонес, Д. Літлер, Г. Мацієвський, М. Ліповський, Т. Кушваха, Х. Хохлі, М.Д. Клемес, М.В. Непомучено, А. Пармент, Н. Луман, Е. Лібанова, Д. Статm, А. Джупта та ін. Показано, що рішення споживачів про купівлю завжди пов'язані з ризиком. Ризик впливає на зміни в споживчих рішеннях, відкладаючи їх або просто відміняючи, але лише тоді, коли його усвідомлює споживач. Розглянуто ризики, пов'язані з придбанням товару споживачами, та ризики, пов'язані з місцем/способом придбання товару. Зазначено, що ризик при придбанні послуг, як правило, вищий, ніж у разі купівлі матеріальних товарів. Проаналізовано сім категорій усвідомленого ризику (функціональний, фрізичний, фрінансовий, матеріальний, соціальний, психологічний i ризик часу). Виокремлено основні фактори, з якими пов'язана величина ризику: 1) кількість можливих альтернатив для задоволення певної потреби, 2) усвідомлена взаємозамінність цих альтернатив, 3) їх значимість i4) взаємна схожість альтернатив. Описано такі два типи ризику, як «завжди існуючий» ризик $і$ «ризик рішення». Зроблено висновок, що усвідомлений ризик зумовлений не тільки суб'єктивним сприйманням споживача, а й відносною новизною каналу збуту. Указані заходи щодо зменшення ризику при купівлі продукції, а також ризику, пов'язаного з місчем/способом придбання товару. Зазначено, що дуже важливим способом зменшення усвідомленого ризику є підвищення знань споживача про товар, що купується.

Ключові слова: ризик, усвідомлений ризик, величина ризику, «завжди існуючий» ризик, «ризик рішення», поведінка споживача.
The theoretical bases of studying of risk as one of defining determinants of consumer behavior of individuals of such researchers as U. Beck, R. A. Bauer, V. W. Mitchell, L. Garbarski, L. Rudnicki, A. Jonas, D. Littler, G. Maciejewski, M. Lipowski, T. Kushwaha, H. Hoehle, M.D. Clemes, M.V. Nepomuceno, A. Parment, N. Luman, E. Libanova, D. Statt, A. Gupta and others are considered in the article. It is shown that consumer's decisions to buy are always associated with risk. Risk affects changes in consumer decisions, postponing them or simply canceling them, but only when the consumer recognizes it. The risks associated with the purchase of goods by consumers and the risks associated with the place/method of purchase of goods are considered. It is noted that the risk when purchasing services is usually higher than in the case of purchasing tangible goods. Seven categories of perceived risk (functional, physical, financial, material, social, psychological and time risk) were analyzed. The main factors associated with the magnitude of risk are identified: 1) the number of possible alternatives to meet a particular need, 2) the perceived interchangeability of these alternatives, 3) their importance and 4) the mutual similarity of alternatives. Two types of risk are described, such as "intrinsic" risk and "decision risk". It is concluded that the perceived risk is due not only to the subjective perception of the consumer, but also the relative novelty of the sales channel. Discussed measures to reduce the risk when buying products and the risk associated with the place / method of purchase of goods. It is noted that a very important way to reduce perceived risk is to increase consumer knowledge about the product being purchased.

Key words: risk, perceived risk, the magnitude of the risk, "intrinsic" risk, "decision risk", consumer behavior.
Постановка проблеми. За сучасних умов питання споживчої поведінки індивідів і їі детермінанти стає однією з найцікавіших теоретичних і водночас найважливіших практичних проблем сучасної соціології. Важливість цього питання зумовлена тим, що зі зростанням рівня життя, розвитком виробництва, появою нових товарів і послуг, які відповідають потребам споживачів (як і давно існуючим, так і новоствореним), а також цивілізаційним і культурним змінам, швидкими темпами змінюються також і преференції споживачів і способи здійснення ними покупок.

Споживча поведінка індивідів охоплює послідовний набір реакцій, пов'язаних зі здійсненням вибору, спрямованих на задоволення індивідуальних потреб шляхом придбання конкретних матеріальних товарів і послуг. Отже, це процес, що включає діяльність, пов'язану з прийняттям рішень, починаючи від усвідом- лення потреби й закінчуючи оцінкою споживачем правильності прийнятого рішення. Купівельна поведінка споживачів $€$ результатом взаємодії багатьох детермінант, що діють із різною силою й у різних напрямах. Однією з таких детермінант саме i $€$ ризик, який $€$ об'єктом дослідження статті. Усе це пояснює актуальність обраної для дослідження теми.

Аналіз останніх досліджень і публікацій. Дослідженням ризику як одного з визначальних детермінант споживчої поведінки індивідів займалися такі дослідники, як У. Бек, Р.А. Бауер, В.В. Мітчел, Л. Гарбарський, Л. Рудницький, А. Джонес, Д. Літлер, Г. Мацієвський, М. Ліповський, Т. Кушваха, Х. Хохлі, М.Д. Клемес, М.В. Непомуцено, А. Пармент, Н. Луман, Е. Лібанова, Д. Статт, А. Джупта та ін.

Постановка завдання. Метою статті $€$ представлення ризику як одного з визначальних факторів споживчої поведінки індивідів. 
Виклад основного матеріалу дослідження. Сьогодні ризик - це сфера досліджень представників багатьох наукових дисциплін - соціологів, психологів, економістів, юристів, осіб, пов'язаних з управлінням, медициною та технологіями. Завдяки дедалі глибшим взаємозв'язкам різних сфер суспільного й економічного життя, з'явилася нова галузь знань, яка ставить ризик у центр своїх інтересів, відома як «управління ризиками» - інтегроване управління диверсифікованим ризиком. Міждисциплінарний характер ризику створює багато проблем для дослідників 3 погляду основних понять, визначень і використовуваної термінології. Створенню єдиного універсального визначення ризику також не сприяє етимологія самого слова «ризик», яка досі чітко не пояснена.

Розглянемо, як це поняття пояснюється із соціологічного погляду.

\section{1. Поняття ризику в соціології.}

У соціології ризик розглядають із різних теоретичних точок зору. Загалом можна виокремити три різні підходи до трактування ризику:

- концепція керованості (М. Фуко), яка визначає ризик як інституційно конструйовану категорію, що дає змогу здійснювати моніторинг і спрямовувати суспільну діяльність, спрямовану на зменшення невизначеності;

- концепція суспільства ризику (У. Бек [5], Е. Гідденс), у якій можна виокремити два підходи: (1) ризик як небажаний ефект розвитку знань і технологій, що не підлягає контролю традиційних соціальних інститутів, і (2) ризик як невизначеність, що характеризує існування особи без підтримки традиційних соціальних інститутів;

- соціокультурна концепція (М. Дуглас, А. Вільдавський), що розглядає ризик як категорію, сформульовану на основі загальновизнаних у культурі припущень, очікувань і наслідків, що дає змогу ідентифікувати ті групи та установи, об'єкти та події, які становлять потенційну загрозу.

Українська дослідниця Е. Лібанова, визначає ризик як кількісну міру небезпеки, тобто ймовірність настання небажаної події, і як максимальний збиток, котрий супроводжується цією подією. Крім того, ризик визначається як можливе мірило виникнення техногенних іприродних явищ, що супроводжуються формуванням і впливом шкідливих факторів, а також завданим при цьому соціальним, екологічним, економічним чи іншим збитком [2, с. 103].

Дослідник Н. Луман трактує ризик як один із показників невизначеності: «Ризик - це певною мірою все, що може погано закінчитися. «Безпеку» ми визначаємо як протилежне йому поняття, однак відразу ж додаємо, що безпека в суворому, вільному від ризику сенсі взагалі не існує. Це означає, що й поняття ризику в подібному розумінні є універсальним поняттям, яке не виключає нічого, а лише маркує само себе в контексті власної форми» [1, с. 242-243].

Ризик виникає при прийнятті рішень щодо майбутнього. Фізична особа (наприклад, споживач) або юридична особа (наприклад, підприємство), яка здійснює більш-менш диверсифіковану діяльність, не впевнена в майбутніх результатах. Працювати за умов ризику через невідоме майбутнє означає приймати рішення за відсутності повної інформації. Досягти поставленої мети можливо, але не надійно. Зміни, що надходять із довкілля, впливають на учасників ринку, створюючи стан невизначеності.

Отже, через недостатню чіткість у категоріях ризику визначення цього поняття вимагає багатьох компромісів. Найчастіше те, що вважається небезпекою чи шкодою, залежить від культурних умов, які з часом змінюються. Тому не існує постійної точки відліку для формулювання єдиного, об'єктивного та універсального визначення ризику, яке відповідало б очікуванням представників багатьох різних наукових дисциплін, що займаються цією проблемою. Визначення ризику, сформульовані на основі різних дисциплін, не тільки суттєво відрізняються одне від одного, а й у них викристалізувалися певні напрями. Вони мають на меті визначити поняття невизначеності й ризику для власного внутрішньодисциплінарного використання.

У поведінці споживачів прийняття рішення про придбання товару пов'язано з багатьма невідомими. Результат вибору часто ненадійний. Навіть невибрані альтернативи мають привабливі риси, важко уникнути когнітивного дисонансу. Ці сумніви, що супроводжують процес прийняття рішення про покупку, пов'язані з усвідомленням конкретних ризиків. Розглянемо тепер це поняття саме в площині поведінки споживача.

\section{2. Ризик, пов'язаний із придбанням} товару.

Рішення споживачів про купівлю завжди пов'язані з ризиком [8, с. 348]. Він впливає на зміни в цих рішеннях, відкладаючи їх або просто уникаючи, але лише тоді, коли його помічає покупець. Його усвідомлення, незалежно від того існує він чи ні, $є$ необхідною умовою для детермінування поведінки споживача [14, с. 49]. Отже, усвідомлення ризику призводить до модифікації прийнятих рішень про купівлю, оскільки купівельна поведінка може мати негативні наслідки.

Ризик, який усвідомлюється споживачем, - це вид невизначеності, з яким він стикається, коли неможливо передбачити важливі наслідки прийнятих рішень [7, с. 49]. Тому ризик виникає тоді, коли споживачі усвідом- 
люють небезпеку прийняття неправильного рішення й бояться, що його наслідки будуть для них значними. На основі моделі, розробленої Пітером і Райаном [15, с. 163-187], величина ризику, що усвідомлюється споживачами, є добутком двох складників: імовірності появи негативних наслідків цього рішення та значення (важливості) негативних наслідків.

Величина ризику при купівлі, який несуть споживачі, дуже різниться. Він багато в чому залежить від типу придбаного товару (набагато більший ризик зазвичай супроводжує придбання дорогих парфумів чи крему, ніж дезодоранту), знань про товар, відносної фінансової вартості покупки, способу придбання, очікувань від товару чи особистості споживача.

Загалом фактори, з якими пов'язана величина ризику, ми можемо звести до основних чотирьох: 1) кількістю можливих альтернатив для задоволення цієї потреби, 2) усвідомленою взаємозамінністю цих альтернатив, 3) їх значимістю; 4) взаємною схожістю альтернатив. Чим важливішим є вибір (наприклад, коли товар дорогий), тим більше між собою $€$ схожими альтернативи, а чим складніше порівняти альтернативи, тим складніше зробити вибір.

Дослідник Р.А. Бауер виокремив сім категорій усвідомленого ризику споживачами [4]:

1. Функціональний ризик - пов'язаний із занепокоєнням споживача щодо здатності товару виконувати певні функції, заради яких товар купується, не працюватиме так, як передбачено, або буде незручним у користуванні. Тому виробники не вводять у товари нові функціональні властивості, якщо властивості ці недостатньо перевірені, якщо вони збільшують ціну на товар більшою мірою, ніж готові платити споживачі.

2. Фізичний ризик - зумовлений головним чином прийняттям рішення, пов'язаного з т. зв. фізичним самопочуттям (безпека вживання ліків, споживання алкоголю або тютюну, використання неалергенної косметики тощо). Для деяких клієнтів головний фактор будь-якої покупки - безпека. Виробники «шкідливих», на думку суспільства, товарів часто пишуть на упаковках, що цей продукт не містить консервантів та інших шкідливих речовин, тим самим знижуючи фізичний усвідомлений ризик.

3. Фінансовий (економічний) ризик - пов'язаний із сумнівами споживачів щодо ціни на продукцію або з майбутніми витратами, пов'язаними з використанням продукції. Споживача хвилює те, чи може він дозволити собі покупку без шкоди для сімейного або особистого бюджету. Цей ризик найвищий для дорогих товарів, а для дешевих він мінімальний.

4. Матеріальний ризик - полягає в загрозі, що якість товару не буде відповідати його ціні. Споживач знає, що є ймовірність наштовхнутися на неякісний товар, тому, щоб мінімізу- вати свої ризики, він готовий заплатити меншу суму, ніж якби на ринку були тільки якісні товари. У результаті в найневигіднішій ситуації опиняються продавці якісних товарів, які змушені знижувати ціну.

5. Соціальний ризик - пов'язаний із вибором, який торкається соціальних відносин і престижу споживача (торгівельні марки з конкретними атрибутами соціального прийняття). Цей ризик набуває все більшої значущості у зв'язку з гіперінноваційністю виробництва й постійною необхідністю адаптуватися до нових товарів. Споживач, для якого характерний цей вид усвідомленого ризику, питає себе: «Що подумає про мене моє оточення?»

6. Психологічний ризик - виникає, коли придбання або використання товару впливає на сприймання власного іміджу або почуття власної гідності. Психологи відзначають, що в момент перед покупкою люди зазвичай відчувають сильні позитивні емоції (бажання володіти річчю, передчуття задоволення і нових можливостей). Після покупки, навпаки, вони стають дуже вразливими й часто жаліють про здійснену покупку. Чим більше сил, часу і грошей людина витратила на покупку, тим сильніше її почуття спустошення.

7. Ризик часу - з'являється тоді, коли виникає необхідність витратити значну кількість часу в процесі придбання або використання товару. В умовах сучасного життя, особливо у великих містах, цей вид усвідомленого ризику стає одним із найважливіших. Споживач не завжди готовий витрачати час на покупку товару. Наприклад, під'їжджаючи до магазину, він може відмовитися зайти в нього, тому що немає місця для паркування.

Згідно з іншою класифікацією, розрізняють такі типи ризику [3]:

1. «Завжди існуючий» ризик - це латентний ризик, властивий певному класу товарів з погляду покупця, внутрішньо притаманна певному товарному класу здатність викликати конфлікт. Необхідність вибирати з безлічі однотипних товарів призводить до купівельного паралічу, при якому більшість споживачів вирішують зовсім відмовитися від покупки. Відомим $€$ експеримент, коли в супермаркеті було встановлено два прилавки з пробниками джему: на одному було представлено 24 варіанти, на другому - 6. При цьому набагато більше людей зупинялися спробувати джем там, де було більше варіантів, але тільки 3\% з них у результаті купили собі джем. До стійки з шістьма видами джему підійшло менше людей, зате $30 \%$ із них вирішили його купити. Отже, споживачі не можуть вибрати з безлічі варіантів, тому що не розуміють, чим один товар відрізняється від іншого.

2. «Ризик рішення» - величина конфлікту, який може бути викликаний цим товаром, коли 
покупець вибирає марку у звичній для нього ситуації здійснення покупки. Люди, що перебувають у стані легкого збудження, розгнівані або голодні, приймають рішення швидше, ніж спокійні. Щасливі люди не приймають ризикованих рішень. Перелякані й засмучені люди відмовляються від прийняття рішення зовсім. Тому, наприклад, продавець не продасть машину, якщо буде багато говорити про її безпеку, тому що змусить покупця подумки пережити аварію.

Природним наслідком напруженості, пов'язаної з ризиком, який усвідомлює споживач, $\epsilon$ бажання його зменшити або усунути. Серед заходів щодо зменшення ризику придбання продукції варто зазначити такі: пошук додаткової інформації та консультацій, особливо серед фахівців (продавці, консультанти, експерти), лояльність до торгівельної марки, вибір відомої марки, здійснення покупки після порівняння декількох/десятка марок, придбання невеликої кількості товару або використання різних видів захисту (пробна покупка, гарантія, безкоштовне тестування зразків тощо) [18, с. 108].

Вибір конкретного товару в умовах ринкової конкуренції містить ризик прийняття неправильного рішення про купівлю, а рівень усвідомленого ризику може відрізнятися залежно від виду товару. Ризик найчастіше пов'язують із купованим товаром, але часто поширюють і на місце/спосіб придбання. Розглянемо цей аспект детальніше.

3. Ризик, пов'язаний із місцем/способом придбання товару.

Усвідомлений ризик покупки в різних каналах збуту може змінюватися і спричинятися абсолютно різними факторами. Через їх природу ризик при придбанні послуг, як правило, вищий, ніж у разі купівлі матеріальних товарів [10, с. 241]. Самі матеріальні товари відрізняються усвідомленим ризиком їх придбання в багатоканальному середовищі. Більшим $€$ ризик, пов'язаний із придбанням електроніки та ювелірних виробів, менший - із купівлею товарів для дому та саду чи товарів для домашніх тварин [11, с. 76]. Усвідомлений ризик покупок щодо категорії товару впливає на преференції у виборі каналу та вартість покупок, здійснених у ньому. При виборі місця купівлі різною може бути схильність до здійснення покупок конкретним способом, наприклад, у фізичних магазинах чи в режимі онлайн, залежно від усвідомленого (вищого чи нижчого) ризику придбання там. Найчастіше при виборі каналів розподілу ця категорія аналізується з погляду використання користувачами електронних каналів доступу до фінансових послуг, що обмежує адаптацію інтернет-каналів у банківській діяльності $[9$, c. 322]. у дослідженнях споживачів щодо використання Інтернет-банкінгу визначено такі види ризиків: фінансовий, функціональний, часовий, соціальний, психологічний і безпековий $[13$, с. 438]. У цьому випадку додаткова категорія безпеки означає загальне уявлення про безпеку/занепокоєння у використанні Інтернету для банківських операцій або ведення рахунків. На основі якісних досліджень ризику безпеки, часу фінансовий і функціональний ризики визначені як значимі для використання цього каналу збуту. Усвідомлення безпеки використання певної технології може різнитися залежно від способу її використання. Дослідження підтверджують, що загальний усвідомлений клієнтами рівень безпеки обслуговування рахунків через веб-сайти є вищий, ніж при використанні мобільних технологій $[12$, с. 175]. Із вищезазначеного спостереження можна зробити висновок, що усвідомлений ризик зумовлений не тільки суб'єктивним сприйманням споживача, а й відносною новизною каналу збуту.

Під час досліджень щодо купівлі товарів через Інтернет споживачі вказують, що найбільший вплив на прийняття рішення про таку трансакцію має усвідомлений ризик придбання, яке найбільшою мірою пов'язане із захистом конфіденційності й безпекою персональних даних, безпекою онлайн-транзакцій і ризиком самого товару [6, с. 371]. Сам ризик, пов'язаний із товаром, виявляється особливо високим при продажах поза магазинами, коли товари певним чином утрачають свої характеристики: до них не можна доторкнутися, приміряти чи випробувати. Тоді особливу роль відіграють функціональний, фінансовий ризики та ризик часу [16, с. 620]. Дослідження показують, що дуже важливим способом зменшення усвідомленого ризику є підвищення знань споживача про товар, що купується. Тоді відчуття безпеки має більший вплив на зменшення усвідомленого ризику, ніж забезпечення відчуття приватності споживача. Особливо важливим для акцептації онлайн покупок є також короткий термін доставки, особливо стосовно товарів, що вимагають тривалого терміну доставки, наприклад, нестандартні або рідкісні товари [8, с. 358].

Значення окремих категорій ризику в купівельній поведінці може бути різним залежно від покоління, тобто детермінуватися віком споживача. Дослідження над преференціями споживачів при здійсненні покупок показує, що покоління $Y$ усвідомлює як особливо важливий соціальний ризик, а Бейбі-Бумерс фінансовий і фізичний [17, с. 192]. Як наслідок, старше покоління починає процес купівлі в надійного продавця, щоб отримати пораду, а молоді споживачі відразу переходять до вибору товару, найчастіше фірмового. 
У результаті аналізу джерел усвідомленого ризику, що виникає в результаті багатоканального розподілу продукції, можна зробити висновок, що в загальному усвідомленні ризику покупок особливо вагоме значення мають функціональний ризик, ризик часу (у якому ключове значення може мати час очікування на доставку товару), безпеки (щодо безпеки транзакцій, платежів, даних) і фінансовий. У результаті, однак, варто зазначити, що кожен із каналів збуту пов'язаний із певними ризиками. У стаціонарному магазині товар може виявитися недоступним або закінчитися термін придатності, а сам магазин може бути далеко від місця проживання споживача, що передбачає ризик непридбання товару, незважаючи на те що витрачаються час і кошти на доїзд. Інтернет-магазин може пропонувати товари, які будуть імпортовані лише для виконання замовлення. Каталог може містити товари, які на відретушованій фотографії виглядають зовсім інакше, ніж насправді.

Оскільки ризик впливає на одержувача тоді, коли він ним усвідомлюється, то, керуючи багатоканальною системою розподілу, варто впливати на ризики, усвідомлені споживачем. Таким, безперечно, є функціональний ризик. Імовірність його настання можна зменшити такими рішеннями: можливість повернення товару протягом тривалого періоду без зазначення причини, обмін на інший товар, детальний опис, велика кількість фотографій, поклики на веб-сайт виробника, полегшення в пристосуванні до потреб споживача (наприклад, можливість додавання фотографій споживача, на які буде накладений товар), система рекомендацій інших покупців.

Ризик часу пов'язаний із невдалою покупкою, а також із відкладанням використання товару. Ризик часу стосується, зокрема, гарантії фізичної доступності товару, терміну та дати доставки, повідомлення про стадію процесу доставки. У сприйманні сучасного споживача час $€$ найунікальнішим ресурсом: раз витрачений, він не може бути відновлений. Отже, ризик часу стосується також подовженого процесу обслуговування/самообслуговування, потреби навчання обслуговуючого персоналу каналу збуту та часу, витраченого на повернення товару. Отже, обмеження цього ризику пов'язане з упевненістю/можливістю перевірки фізичної доступності товару, який покупець хоче придбати, скороченням або гарантуванням терміну доставки, спрощенням/скороченням часу обслуговування.

Зниження ризику безпеки полягає в упевненості виконання правильної транзакції, різноманітності платіжних системи, належного зберігання даних і можливості здійснення транзакцій при збереженні анонімності споживача. Можна зробити так, щоб оплата товару в електронних системах уможливлювала повну анонімність покупця, як це існує в більшості традиційних магазинів. Квитанція, сплачена під час отримання з шафки з посилками (на яку замовлено товар), могла б це повністю забезпечити.

Фінансовий ризик, а саме втрата всіх коштів, призначених на покупку, в основному виникає внаслідок можливості обману споживача або здійснення незворотної покупки товару, який не відповідає очікуванням. Однак фінансовий ризик також включає можливі витрати на доставку, повернення та ремонт, здійснені покупцем. Обмеження усвідомленого фінансового ризику пов'язане з рекомендацією інших каналів у цьому каналі збуту, взаємним системним пов'язуванням різних каналів, що збільшує довіру, завдяки здійсненню покупок в одного й того ж постачальника. Інтернет, де споживачі найчастіше шукають інформацію про товари, можна використовувати як канал збуту, може спрямовувати їх у найближчу торгівельну точку, де вони можуть переглянути товар, або уможливити контакт із працівником через месенджер. Обмеження фінансового ризику також передбачає, що продавець оплачує за доставку, повернення та несе інші витрати, включаючи ремонт, не обтяжуючи ними споживача. Фінансовий ризик можна також знизити, використовуючи маркетингові комунікації для збільшення довіри до каналу збуту.

Висновки 3 проведеного дослідження. Узагальнюючи міркування щодо ризику як детермінанти споживчої купівельної поведінки, представлені в статті, варто погодитися з тезою, що ставить ризик невдалої покупки серед найважливіших детермінант, які впливають на поведінку споживачів. Тим не менше варто мати на увазі припущення, що споживчий ризик доцільно розглядати як важливий чинник поведінки споживачів на ринку лише тоді, коли він $€$ споживачем усвідомлений. I навпаки, той факт, що існує навіть об'єктивно існуючий ризик невдалої покупки, не впливає жодним чином на купівельну поведінку споживача, якщо він індивідом не усвідомлюється.

\section{ЛITЕРАТУРА:}

1. Луман Н. Самоописания / пер. с нем. А. Ановский, Б. Скуратов, К. Тимофреева. Москва : Логос, ИТДГК «Гнозис», 2009. 320 с.

2. Сталий людський розвиток: забезпечення справедливості : нац. доп. / кер. авт. кол. Е.М. Лібанова ; НАН України, Ін-т демографії та соц. досліджень ім. М.В. Птухи. Умань : ВПЦ «Візаві», 2012. 412 c.

3. Статт Д. Психология потребителя / пер. с англ. С. Егорова, Б. Орлова. Санкт-Петербург : Питер, 2003. $446 \mathrm{c}$

4. Bauer R.A. Consumer behavior as risk taking. In : Hancock R.S. (Ed.) Dynamic Marketing for a Changing 
World. Proceedings of the 43rd. Conference of the American Marketing Association, IL. 1960. P. 389-398.

5. Beck U. Społeczeństwo ryzyka. W drodze do innej nowoczesności. Warszawa : Scholar, 2004. 371 s.

6. Clemes M.D., Gan Ch., Zhang J. An empirical analysis of online shopping adoption in Beijing, China. Journal of Retailing and Consumer Services. 2013. Vol. 21 (3).

7. Garbarski L. Zrozumieć nabywcę. Warszawa : PWE, 1994. $162 \mathrm{~s}$.

8. Gupta A., Su B., Walter Z. Risk profile and consumer shopping behavior in electronic and traditional channels. Decision Support Systems. 2004. Vol. 38. P. 347-367.

9. Hoehle H., Scornavacca E., Huff S. Three decades of research on consumer adoption and utilization of electronic banking channels: A literature analysis. Decision Support Systems. 2012. Vol. 54 (1). P. 122-132.

10. Jonas A. Jakość usług a postrzegane przez klientów ryzyko ich zakupu. W : Garbarski L., Tkaczyk J. (red.). Kontrowersje wokół marketingu w Polsce. Niepewność i zaufanie a zachowania nabywców. Warszawa : Wydawnictwa Akademickie i Profesjonalne, 2009. 247 s.

11. Kushwaha T., Shankar V. Are Multichannel Customers Really More Valuable? The Moderating Role of Product Category Characteristics. Journal of Marketing. 2013, Vol. 77 (4). P. 67-85.
12. Lipowski M. Usability of mobile distribution channel for financial services. La Societe de L'information. Perspective Europeenne et Globale, Studia Ekonomiczne. Zeszyty Naukowe Wydziałowe. Uniwersytet Ekonomiczny w Katowicach, 2013, nr 150.

13. Littler D., Melanthiou D. Consumer perceptions of risk and uncertainty and the implications for behaviour towards innovative retail services: The case of Internet Banking. Journal of Retailing and Consumer Services. 2006. Vol. 13. № 6. P. 431-443.

14. Maciejewski G. Ryzyko w decyzjach nabywczych konsumentów. Katowice : W-wo Uniwersytetu Ekonomicznego w Katowicach, 2010. $288 \mathrm{~s}$.

15. Mitchell V. W. Consumer perceived risk: conceptualisations and models. European Journal of Marketing. 1999. Vol. 33. № 1/2. P. 163-195.

16. Nepomuceno M.V., Laroche M., Richard M.-O. How to reduce perceived risk when buying online: The interactions between intangibility, product knowledge, brand familiarity, privacy and security concerns. Journal of Retailing and Consumer Services. 2014. Vol. 21 (4). P. 619-629.

17. Parment A. Generation Y vs. Baby Boomers: Shopping behavior, buyer involvement and implications for retailing. Journal of Retailing and Consumer Services. 2013. Vol. 20 (2). P. 189-199.

18. Rudnicki L. Zachowanie konsumentów na rynku. Warszawa : PWE, 2000. 317 s. 